\title{
ORIGINAL
}

ARTICLES

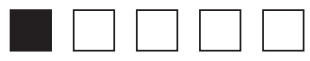

\section{Targeted Medical School Admissions: A Strategic Process for Meeting Our Social Mission}

David V. Evans, MD; Andrew D. Jopson, MPH; C. Holly A. Andrilla, MS; Randall L. Longenecker, MD; Davis G. Patterson, PhD

BACKGROUND AND OBJECTIVES: Increased medical school class sizes and new medical schools have not addressed the workforce inadequacies in primary care or underserved settings. While there is substantial evidence that student attributes predict practice specialty and location, little is known about how schools use these factors in admissions processes. We sought to describe admissions strategies to recruit students likely to practice in primary care or underserved settings.

METHODS: We surveyed admissions personnel at US allopathic and osteopathic medical schools in $\mathbf{2 0 1 8}$ about targeted admissions strategies aimed at recruitment and selection of students likely to practice rurally, in urban underserved areas, or in primary care

RESULTS: One hundred thirty-three of 185 (71.8\%) US medical schools responded. Respondents reported targeted admissions strategies as follows: rural, 69.2\%; urban underserved, $67.4 \%$; and primary care, $45.3 \%$. Nearly $90 \%$ reported some type of recruitment outreach to 4-year universities, but much less to community colleges. Student characteristics used to identify those likely to practice in targeted areas were largely evidence-based. Strategies to select students varied widely.

CONCLUSIONS: Most responding US medical schools reported a targeted process to recruit and select students likely to practice in rural, urban underserved, or primary care settings, indicating widespread awareness of workforce challenges. This study also demonstrates varying approaches to and allocation of resources toward admissions targeting, especially the application and interviewing processes. Understanding how schools identify and admit students likely to practice in these fields is a first step in identifying best practices for selective admissions focused on addressing workforce gaps.

(Fam Med. 2020;52(7):474-82.)

doi: 10.22454/FamMed.2020.470334

S medical schools have a social mission to educate future physicians to meet the needs of the public. ${ }^{1,2}$ However, the US physician workforce does not have enough primary care physicians, and the distribution in all specialties deviates away from rural and urban underserved communities, of this entrustable activity. ${ }^{3-6}$

Simply producing more physicians does not seem to be the answer to meeting this social mission. In the 1970s, class sizes were increased and new medical schools created to build the primary care workforce and improve the geographic distribution

of physicians. The increase in US graduates prompted the Graduate Medical Education National Advisory Committee to predict a physician surplus by 1990 and an appropriate number of primary care physicians, ${ }^{7}$ stalling progress towards previous workforce goals. In 2006, the Association of American Medical Colleges (AAMC), in response to new concerns of a physician shortage, called for a $30 \%$ increase in enrollment in US allopathic medical schools. ${ }^{8}$ Today, US medical school class sizes are increasing, and new schools are being created. Enrollment has increased nearly $30 \%$ in allopathic schools since $2002 .{ }^{9}$ In the same time period, the same factors prompted a $162 \%$ increase in enrollment in osteopathic schools..$^{10}$ Yet, US medical schools are enrolling fewer students from rural backgrounds. ${ }^{11}$ Furthermore, trends indicate that a smaller proportion of US medical students are choosing primary care careers. ${ }^{12}$ In 2019, the National Residency Match Program offered 4,128 positions in family medicine (up 474 from 2018$)$, yet only $1,617(39.2 \%)$ were filled by US graduates (down from 1,648 [45.1\%] in 2018). ${ }^{13}$

A process of medical school recruitment and selection targeted

From the Department of Family Medicine, University of Washington School of Medicine, Seattle, WA (Drs Evans and Patterson, Mr Jopson, and Ms Andrilla); and the Ohio University Heritage College of Osteopathic Medicine, Athens, OH (Dr Longenecker). 
to individual applicant characteristics is one tool to systematically address medical schools' social missions. Place of upbringing is related to similar place of practice for both rural ${ }^{14-19}$ and urban ${ }^{20-22}$ students. Students' demonstrated interest in underserved practice and family medicine is associated with entry into primary care and care for underserved populations. . $^{16,21,23,24}$ Those from underrepresented groups in medicine (URM) ${ }^{25}$ are also more likely to enter underserved practice. ${ }^{14,21,26,27}$ In a 2016 systematic review of the literature, Goodfellow et $\mathrm{a}^{28}$ examined predictors of primary care practice location in underserved and rural areas, finding 19 studies focused on physician characteristics that inform admissions practices. The studies reported positive associations between URM status, second language fluency, growing up in an inner city, growing up in a rural area, and prior interest in underserved practice and family medicine. They further stated that while these associations are known, the literature is scant with respect to how schools use these personal factors in their admissions criteria.

The often-discussed physician pipeline is long. Who gets into medical school is a critical juncture that is key to how and where graduates practice. To address this, some schools developed targeted admissions policies to recruit and admit students likely to meet mission-driven workforce needs. ${ }^{29-33}$ Schools use these targeting policies to selectively admit students likely to practice in rural areas, in urban underserved areas, and in primary care. However, little is known about the extent to which medical schools use targeted admissions approaches to both recruit and select the desired students. Even less is known about their recruitment and selection strategies, screening and interview processes, and the degree to which targeting is evidence-based. This national study examines the targeted admissions policies and practices of US allopathic and osteopathic medical schools.

\section{Methods}

\section{Sampling Frame}

We compiled a list of allopathic and osteopathic medical schools in the United States from online directories on the American Association of College of Osteopathic Medicine, ${ }^{34}$ American Osteopathic Association, ${ }^{35}$ and $\mathrm{AAMC}^{36}$ websites during the fall of 2017. We excluded schools in Puerto Rico. We identified 147 allopathic and 39 osteopathic schools for a total study population of 186 . We identified up to three key personnel contacts involved in designing admissions policies for each school from its website or via Google search, including anyone with position titles such as "Dean of Admissions," "Director of Admissions," "Assistant Dean for Admissions," or "Admissions Coordinator." We emailed personalized online survey questionnaire links to the highest ranked at each medical school via Research Electronic Data Capture (REDCap) from January through July 2018, making up to 20 follow-up attempts to each medical school using a combination of email reminders through REDCap, phone calls, and personal emails. During follow-up, we learned that two allopathic medical schools shared the same admissions process, reducing our study population to 185 . The human research committees at the University of Washington, Ohio University and University of North Dakota approved this study as exempt.

\section{Questionnaire}

We designed the survey questionnaire based on available literature on targeted admissions strategies and research team expertise. The questionnaire asked, "Does your medical school target applicants likely to (1) practice in rural areas in recruiting or selecting prospective students during the admissions process? (2) practice in urban underserved areas in recruiting or selecting prospective students during the admissions process? and (3) enter primary care practice in recruiting or selecting prospective students during the admissions process?" We defined primary care practice as general internal medicine, general pediatrics, and family medicine. The questionnaire asked respondents answering yes to any of these questions to answer supplementary questions about their recruitment and admissions processes.

To assess how medical schools recruit applicants likely to practice in targeted areas, the questionnaire asked whether schools engage in premedical enrichment activities and partnerships. Relying on enrichment program typologies for precollege and college students developed by Carline et $\mathrm{al}^{32,33}$ we grouped these activities and partnerships into four categories: (1) career exploration, career counseling, and/or mentorship; (2) academic enhancement (eg, study skills, MCAT preparation, etc); (3) medical school admissions preparation (eg, application preparation, mock interviews); and (4) articulation agreements, defined as a formal agreement between two academic institutions documenting admissions or transfer policies for a specific academic program. For each of these categories, we asked whether schools engage with students in high school, Area Health Education Center (AHEC) programs, community and technical colleges, 4-year universities, or postbaccalaureate programs.

To understand how medical schools identify and select applicants likely to practice in targeted areas, the questionnaire asked whether schools use certain characteristics or questions in their secondary application to identify these applicants, based on the literature relevant to each applicant group..$^{16,20,21,24,37-49}$

To understand how the admissions process differs for these applicants, the questionnaire asked whether schools did any of the following: modify Medical College Admission Test (MCAT) score cutoffs, modify grade point average (GPA) cutoffs, offer focused financial aid, reserve slots in entering classes, give preferential scoring in interview screening, give preferential scoring in final admissions determination, 
conduct separate interviews, or ask different interview questions from other applicants.

Lastly, the questionnaire asked about who was involved in implementing the targeted admissions strategy and whether physicians who practice in rural areas, urban underserved areas, or primary care are part of the interview team.

\section{Analysis}

We used Stata SE v. 14.0 (StataCorp, 2015, College Station, TX) to perform all statistical analyses, calculating descriptive statistics on targeted admissions strategies. Chi-square tests for independence were used to examine differences in school characteristics by each targeted admissions strategy. The significance level was set at $P<.05$. "Don't know," "Not applicable," and no responses were coded as missing values and excluded from the denominator when calculating percentages for each target group.

\section{Results}

The overall response rate was 71.8\% (133 responses: 106 allopathic schools and 27 osteopathic schools) Response rates for allopathic and osteopathic schools were similar (72.6\% vs $69.2 \%)$. To estimate nonresponse bias, we compared respondent and nonrespondent schools and found no statistically significant difference between the groups by allopathic/osteopathic status $(P=.68)$ or public/private status $(P=.12)$. Respondent schools were significantly different from nonrespondent schools by US Census Region $(P<.01)$.

Table 1 shows school characteristics and the proportion of schools that reported targeted admissions strategies (rural, urban underserved, primary care). Table 2 shows the number and proportion of schools with targeted admissions strategies by school characteristics. We compared school characteristics within each strategy, and found that more osteopathic schools $(76.0 \%)$ reported a primary care admissions strategy than allopathic schools (37.9\%, $\left.\chi^{2}[1]=11.8, P<.01\right)$ and more public schools $(65.2 \%)$ than private schools $\left(39.0 \%, \chi^{2}(1)=7.9, P<.01\right)$ reported a rural targeted admissions strategy. There was a statistically significant

Table 1: Characteristics and Targeted Strategies of Respondent US Medical Schools in 2018

\begin{tabular}{|l|c|}
\hline \multicolumn{1}{|c|}{ Public/Private Institution } & \begin{tabular}{c} 
Respondent $\begin{array}{c}\text { Medical Schools, N=133 } \\
\text { n (\%) }\end{array}$ \\
\hline Public
\end{tabular} \\
\hline Private & $76(57.1)$ \\
\hline \multicolumn{1}{|c|}{ Allopathic/Osteopathic } & $57(42.9)$ \\
\hline Allopathic & $106(79.7)$ \\
\hline Osteopathic $\quad 27(20.3)$ \\
\hline \multicolumn{1}{|c|}{ Census Region } & $23(17.3)$ \\
\hline Northeast & $37(27.8)$ \\
\hline Midwest & $47(35.3)$ \\
\hline South & $26(19.6)$ \\
\hline West & \\
\hline \multicolumn{1}{|c|}{ Targeted Admissions Strategy } & $92(69.2)$ \\
\hline Rural & $89(67.4)$ \\
\hline Urban underserved ${ }^{\text {a }}$ & $58(45.3)$ \\
\hline Primary care practice ${ }^{\text {b }}$ & \\
\hline
\end{tabular}

a Total $\mathrm{n}=132$ due to missing data.

b Total $\mathrm{n}=128$ due to missing data. relationship between Census Region and rural targeting, with the South most likely to have rural targeting (80.9\%) followed by the Midwest $(70.3 \%)$, West $(69.2 \%)$ and Northeast $(43.5 \%)$. We found no statistically significant associations across school characteristics for those with urban underserved targeted admissions strategies.

\section{Targeted Admissions Strategies}

Responding schools reported targeted admissions strategies as follows: rurally targeted, $69.2 \%(\mathrm{n}=133)$; urban underserved-targeted, $67.4 \%$ $(\mathrm{n}=132)$; and primary care-targeted, $45.3 \%(\mathrm{n}=128)$.

\section{Rurally Targeted Admissions.} Most schools recruiting students likely to practice in rural areas focused their recruitment strategies on career exploration, career counseling, and/or mentorship as well as on students from 4-year universities (Table 3); 89.9\% of schools targeting rural students engaged students from 4-year universities in career exploration, career counseling, and/ or mentorship; $57.5 \%$ provided medical school admissions preparation; and $47.7 \%$ engaged in academic enhancement activities. Nearly half of schools (42.9\%) reported having an articulation agreement with a 4-year university to recruit students likely to practice in rural areas.

Applicant characteristics used by schools with rurally targeted admissions are shown in Table 4. All but one school used these evidence-based characteristics to identify applicants. Nearly three-quarters $(74.7 \%)$ indicated that their secondary application contained questions that helped to identify applicants likely to practice in rural areas.

Some schools modified the admissions process for applicants identified as likely to practice in rural areas (Table 5). Most used secondary applications to help identify and select students likely to practice in a rural area. A minority reported giving preferential scoring in interview screening $(38.2 \%)$ or preferential 
Table 2: Number and Percentage of Respondent US Medical Schools With Targeted Admissions Strategies in 2018, Categorized by School Characteristics

\begin{tabular}{|c|c|c|c|c|}
\hline & \multicolumn{3}{|c|}{ Medical Schools by Target Group, n (\%) } & \multirow[b]{2}{*}{$\begin{array}{c}\text { Number of Responding } \\
\text { Schools }\end{array}$} \\
\hline & Rural & Urban Underserved & Primary Care Practice & \\
\hline \multicolumn{5}{|c|}{ Public/Private Institution } \\
\hline Public & $60(79.0)$ & $51(67.1)$ & $33(44.6)$ & 76 \\
\hline Private & $32(56.1)$ & $38(67.9)$ & $25(46.3)$ & 57 \\
\hline \multicolumn{5}{|c|}{ Allopathic/Osteopathic } \\
\hline Allopathic & $70(66.0)$ & $70(66.7)$ & $39(37.9)$ & 106 \\
\hline Osteopathic & $22(81.5)$ & $19(70.4)$ & $19(76.0)$ & 27 \\
\hline \multicolumn{5}{|c|}{ Census Region } \\
\hline Northeast & $10(43.5)$ & $17(77.3)$ & $9(45.0)$ & 23 \\
\hline Midwest & $26(70.3)$ & $27(73.0)$ & $12(34.3)$ & 37 \\
\hline South & $38(80.9)$ & $27(57.5)$ & $28(59.6)$ & 47 \\
\hline West & $18(69.2)$ & $18(69.2)$ & $9(34.6)$ & 26 \\
\hline
\end{tabular}

Of the 133 medical schools that responded, 92 reported a rural targeted strategy, 89 reported an urban underserved targeted strategy, and 58 reported a primary care practice targeted strategy.

Table 3: Recruitment Activities by US Medical Schools in 2018 to Target Students Likely to Enter Rural, Urban Underserved, or Primary Care Practice

\begin{tabular}{|c|c|c|c|}
\hline & \multicolumn{3}{|c|}{ Medical Schools by Target Group } \\
\hline & Rural ( $n=92)$ & $\begin{array}{c}\text { Urban } \\
\text { Underserved } \\
(n=89)\end{array}$ & $\begin{array}{c}\text { Primary } \\
\text { Care }(n=58)\end{array}$ \\
\hline \multicolumn{4}{|l|}{ Career Exploration, Career Counseling, and/or Mentorship } \\
\hline High schools, n (\%) & $75(83.3)$ & $70(83.3)$ & $40(71.4)$ \\
\hline Area Health Education Center (AHEC) programs, n (\%) & $54(66.7)$ & $37(52.1)$ & $27(56.3)$ \\
\hline Community and technical colleges, $\mathrm{n}(\%)$ & $54(62.1)$ & $38(48.7)$ & $27(50.9)$ \\
\hline 4-year universities, n (\%) & $80(89.9)$ & $74(87.1)$ & $40(74.1)$ \\
\hline Postbaccalaureate programs, n (\%) & $60(68.2)$ & $61(74.4)$ & $32(59.3)$ \\
\hline \multicolumn{4}{|l|}{ Academic Enhancement } \\
\hline High schools, n (\%) & $24(28.2)$ & $37(44.6)$ & $21(38.2)$ \\
\hline Area Health Education Center (AHEC) programs, n (\%) & $20(24.7)$ & $19(26.8)$ & $12(24.5)$ \\
\hline Community and technical colleges, $\mathrm{n}(\%)$ & $19(22.4)$ & $26(32.5)$ & $11(21.6)$ \\
\hline 4-year universities, n (\%) & $41(47.7)$ & $47(54.7)$ & $22(40.7)$ \\
\hline Postbaccalaureate programs, n (\%) & $40(45.5)$ & $39(46.6)$ & $18(33.3)$ \\
\hline \multicolumn{4}{|l|}{ Admissions Preparation } \\
\hline Community and technical colleges, $\mathrm{n}(\%)$ & $30(35.7)$ & $33(40.2)$ & $20(37.0)$ \\
\hline Four-year universities, n (\%) & $50(57.5)$ & $55(64.0)$ & $32(58.2)$ \\
\hline Postbaccalaureate programs, n (\%) & $41(46.6)$ & $47(55.3)$ & $28(51.9)$ \\
\hline \multicolumn{4}{|l|}{ Articulation Agreement } \\
\hline Community and technical colleges, $\mathrm{n}(\%)$ & $6(7.2)$ & $5(5.9)$ & $4(7.1)$ \\
\hline 4-year universities, n (\%) & $36(42.9)$ & $29(33.7)$ & $22(39.3)$ \\
\hline Postbaccalaureate programs, n (\%) & $17(20.5)$ & $15(17.6)$ & $14(25.0)$ \\
\hline
\end{tabular}

"Don't know," "Not applicable," and no responses were coded as missing values and excluded from the denominator when calculating these percentages. Missing values for each question item ranged from 2 to 18. Interested readers may calculate the missing value for each question item by dividing $\mathrm{n}$ schools by the percentage and subtracting that number from the number of medical schools at the top of the column. 
scoring in final admissions determinations (30.0\%); $20.2 \%$ reserved slots in the entering class for applicants likely to practice in a rural area. About one-fifth of schools modified MCAT $(21.4 \%)$ or GPA cutoffs (18.8\%). Medical schools with separate interviews (11.2\%) or different interview questions than other applicants $(6.8 \%)$ were less common (Table 4).

Urban Underserved Targeted Admissions. To recruit students likely to practice in urban underserved areas, $87.1 \%$ of schools engaged in career exploration, career counseling, and/or mentorship with students from 4-year universities, 83.3\% with high school students, and $48.7 \%$ with community colleges. A little over half (54.7\%) of schools engaged in academic enhancement activities and $64.0 \%$ engaged in admissions preparation with students from 4-year universities. About one-third reported enhancement activities (32.5\%) and preparation activities $(40.2 \%)$ with community colleges. One-third (33.7\%) reported articulation agreements with 4-year universities to recruit students likely to practice in urban underserved areas (Table 3).

Of the 89 medical schools that reported targeting applicants likely to practice in urban underserved areas, the most common criterion used to identify applicants was "stated interest in practicing in underserved area" (97.6\%). About half (51.2\%) reported using an applicant's "noncontinuous path from high school" (eg, another career prior to applying to medical school) to indicate a likelihood to practice in urban underserved areas (Table 4).

We found that medical schools with targeted admissions for students likely to enter urban underserved practices altered their admissions process in ways similar to rurally targeted strategies (Table 5). Almost two-thirds (65.9\%) had questions on their secondary application to identify applicants for preferential selection. One-third (33.3\%) gave preferential scoring in interview screening and one-fourth $(24.4 \%)$ of schools gave preferential scoring in final admissions determinations; $24.4 \%$ modified MCAT cutoffs and $22.9 \%$ modified GPA cutoffs; $18.8 \%$ reserved slots in each entering class explicitly for applicants likely to practice in urban underserved areas. Scheduling separate interviews $(8.1 \%)$ or asking different interview questions $(3.5 \%)$ was less common.

Primary Care Practice Targeted Admissions. To recruit students likely to enter primary care, a majority of responding schools engaged in career exploration, career counseling, and/or mentorship with students from post-high school educational institutions. Fewer schools reported engaging in academic enhancement activities and admissions preparation. Over one-third (39.3\%) reported

Table 4: Characteristics of Applicants Used by US Medical Schools in 2018 to Identify Students Likely to Enter Rural, Urban Underserved, or Primary Care Practice

\begin{tabular}{|l|c|c|c|}
\hline \multicolumn{1}{|c|}{ Applicant Characteristic } & \multicolumn{2}{c|}{ Medical Schools by Target Group } \\
\cline { 2 - 4 } & $\begin{array}{c}\text { Rural } \\
\text { (n=92) }\end{array}$ & $\begin{array}{c}\text { Underserved } \\
\text { Un=89) }\end{array}$ & $\begin{array}{c}\text { Primary Care } \\
\text { (n=58) }\end{array}$ \\
\hline Graduated from a rural high school, ${ }^{37,38} \mathrm{n}(\%)$ & $69(76.7)$ & - & - \\
\hline Grew up in a rural community, ${ }^{39,40,46} \mathrm{n}(\%)$ & $89(97.8)$ & - & $45(78.9)$ \\
\hline Provided volunteer service in a rural community, $\mathrm{n}(\%)$ & $72(80.9)$ & - & - \\
\hline Previously employed in a rural community, $\mathrm{n}(\%)$ & $56(66.7)$ & - & - \\
\hline Applicant's partner/spouse is receptive to rural living, ${ }^{64} \mathrm{n}(\%)$ & $10(13.7)$ & - & - \\
\hline Graduated or expected graduation from public college or university, ${ }^{41,43} \mathrm{n}(\%)$ & $27(32.1)$ & - & - \\
\hline Positive rural exposure, ${ }^{64} \mathrm{n}(\%)$ & $45(52.9)$ & - \\
\hline Stated interest in family medicine, ${ }^{16,24,41,43,67} \mathrm{n}(\%)$ & $61(70.1)$ & - \\
\hline Non-continuous path from high school, ${ }^{43} \mathrm{n}(\%)$ & $37(43.0)$ & $41(51.2)$ & $25(49.0)$ \\
\hline Member of a group underrepresented in medicine, ${ }^{20,21,42,45} \mathrm{n}(\%)$ & $69(79.3)$ & $82(93.2)$ & $41(73.2)$ \\
\hline Grew up in underserved area, ${ }^{21,68,} \mathrm{n}(\%)$ & - & $81(92.0)$ & - \\
\hline Stated interest in/commitment to practicing in underserved area, ${ }^{21,44,68} \mathrm{n}(\%)$ & - & $83(97.6)$ & - \\
\hline Possessing altruistic beliefs about health care, ${ }^{47,48,9,70} \mathrm{n}(\%)$ & - & - \\
\hline Stated interest in/commitment to primary care prior to medical school, ${ }^{68} \mathrm{n}(\%)$ & - & $47(85.5)$ \\
\hline
\end{tabular}

"Don't know," "Not applicable," and no responses were coded as missing values and excluded from the denominator when calculating these percentages. Missing values for each question item ranged from 1 to 9 . Interested readers may calculate the missing value for each question item by dividing $\mathrm{n}$ schools by the percentage and subtracting that number from the number of medical schools at the top of the column. Evidence-based applicant characteristics for identifying students likely to enter rural, urban underserved, or primary care practice are noted by reference list number(s). 
articulation agreements with 4-year universities to recruit students likely to enter primary care, while $7.1 \%$ had similar agreements with community colleges (Table 3 ).

Of the 58 medical schools that reported targeting applicants likely to enter primary care practice, nearly all used "stated interest in/commitment to practicing in underserved area" $(98.2 \%)$ or "stated interest in/ commitment to primary care prior to medical school" (98.2\%) to identify these applicants (Table 4); $80.0 \%$ reported having questions on their secondary application to identify these applicants. About one-quarter of schools used preferential scoring in interview screening and on final admissions determination. Medical schools with separate interviews $(5.3 \%)$ or different interview questions than other applicants (1.8\%) were rare (Table 5).

\section{Discussion}

The social mission of US medical schools is educating physicians to serve the needs of the country. Over the last 50 years, considerable effort has been made to meet these goals yet there remain too few family physicians and rural and urban underserved communities continue to lack an adequate physician workforce. ${ }^{50-52}$ More recently, family medicine organizations launched the America Needs More Family Doctors: 25 x 2030 Collaborative initiative to address these issues..$^{53}$ In our national study of US allopathic and osteopathic medical schools, a majority reported targeted admissions policies aimed at students likely to practice in rural, urban underserved, or primary care settings, indicating a widespread awareness of these issues and effort to ameliorate these disparities. Despite this awareness, our study demonstrates widely varying approaches to and allocation of resources toward admissions targeting, especially with respect to the application and interviewing processes.

Differences in targeted admissions practices were associated with some school characteristics. It is not surprising that osteopathic schools reported more targeting toward primary care because they produce a higher proportion of primary care physicians, especially family physicians. ${ }^{54-57}$ Similarly, public schools, which may be more attentive to regional workforce needs, are more likely to have targeted rural admissions. The difference in rural targeted admissions across census regions may reflect perceived regional workforce needs and/or differences in the number of public and private schools in the region. The finding of no differences across school characteristics

Table 5: Selection Strategies by US Medical Schools in 2018 to Select Students Likely to Enter Rural, Urban Underserved, or Primary Care Practice

\begin{tabular}{|c|c|c|c|}
\hline \multirow[b]{2}{*}{ Selection Strategy } & \multicolumn{3}{|c|}{ Medical Schools by Target Group } \\
\hline & $\begin{array}{c}\text { Rural } \\
(n=92)\end{array}$ & $\begin{array}{c}\text { Urban } \\
\text { Underserved } \\
(n=89)\end{array}$ & $\begin{array}{c}\text { Primary } \\
\text { Care } \\
(n=58)\end{array}$ \\
\hline \multicolumn{4}{|l|}{ Application } \\
\hline Secondary application questions, $\mathrm{n}(\%)$ & $65(74.7)$ & $56(65.9)$ & $44(80.0)$ \\
\hline Offer targeted financial aid, n (\%) & $33(37.1)$ & $39(45.9)$ & $18(32.1)$ \\
\hline Modify MCAT cutoffs, n (\%) & $18(21.4)$ & $20(24.4)$ & $4(7.3)$ \\
\hline Reserve slots in each entering class, $\mathrm{n}(\%)$ & $18(20.2)$ & $16(18.8)$ & $10(18.2)$ \\
\hline Modify GPA cutoffs, n (\%) & $16(18.8)$ & $19(22.9)$ & $4(7.4)$ \\
\hline \multicolumn{4}{|l|}{ Interview } \\
\hline Physicians practicing in rural, urban underserved, or in primary care setting, $\mathrm{n}(\%)$ & $65(75.6)$ & $64(81.0)$ & $53(94.6)$ \\
\hline Preferential scoring in interview screening, n (\%) & $34(38.2)$ & 29 (33.3) & $16(27.6)$ \\
\hline Preferential scoring in final admissions determination, $\mathrm{n}(\%)$ & $27(30.0)$ & $21(24.4)$ & $13(23.2)$ \\
\hline Undergo other admissions process, $\mathrm{n}(\%)$ & 13 (14.6) & $10(11.5)$ & $6(10.3)$ \\
\hline Separate interviews than other applicants, $\mathrm{n}(\%)$ & $10(11.2)$ & $7(8.1)$ & $3(5.3)$ \\
\hline Different interview questions than other applicants, $\mathrm{n}(\%)$ & $6(6.8)$ & $3(3.5)$ & $1(1.8)$ \\
\hline \multicolumn{4}{|l|}{ Key Personnel Involved } \\
\hline Dean of admissions, $\mathrm{n}(\%)$ & $76(89.4)$ & 79 (92.9) & $48(88.9)$ \\
\hline Physicians practicing in specific area, $\mathrm{n}(\%)$ & $59(72.0)$ & $61(78.2)$ & $45(83.3)$ \\
\hline Director of specific track or equivalent, $\mathrm{n}(\%)$ & $46(61.3)$ & $29(42.0)$ & $26(55.3)$ \\
\hline
\end{tabular}

"Don't know," "Not applicable," and no responses were coded as missing values and excluded from the denominator when calculating these percentages. Missing values for each question item ranged from 2 to 22 . Interested readers may calculate the missing value for each question item by dividing $\mathrm{n}$ schools by the percentage and subtracting that number from the number of medical schools at the top of the column. 
with respect to urban underserved admissions policies is difficult to interpret. Medical schools tend to be located in urban areas and they may be more uniformly aware of urban workforce needs. More research is needed on the relationships between medical school characteristics and school production of physicians working in these needed domains.

We found that applicant characteristics used for targeting tended to be evidence-based..$^{16,20,21,24,37-49}$ In all three areas we studied, most schools that reported targeted admissions strategies used at least one evidencebased criterion for selection.

Most common characteristics used in admissions targeting can be found on the American Medical College Application Service (AMCAS) application, including growing up in a rural community, being a member of a group underrepresented in medicine, or stating an interest in practicing in an underserved area. Respondents reported that more resource-intensive measures like offering financial aid or holding separate interviews were less common. Interventions that may be controversial within large institutions with multiple stakeholders, such as modification of GPA or MCAT cutoffs, were also less commonly used. Failure to adjust MCAT and GPA criteria may be particularly disadvantageous to URM applicants ${ }^{58}$ and those from small rural high schools ${ }^{59}$ as scores tend to be lower in these groups. Substantial alteration of interview practices for targeted populations was uncommon. The vast majority of respondents reporting use of readily available AMCAS metrics, and the relatively low proportion of schools reporting more difficult to enact changes in admissions processes, may account for why schools have not been more successful in addressing workforce needs. More substantial changes with overt resources and commitment may be necessary and is an area for further research.

Only $20 \%$ of schools that reported targeted admissions programs reserved slots in the entering class for the students they sought. Students most inclined to enter the practice areas of need identified in this study are likely to come from small rural high schools, underresourced urban communities, or populations that speak a first language other than English. They are likely to lack advantages of many other medical school applicants and may have trouble competing for coveted medical school seats. Reserving spots in the medical school class for those likely to practice in needed roles may be an additional strategy that schools could employ to further enhance this social mission.

Schools varied in their recruitment activities, but most commonly directed their efforts at 4-year universities. Articulation agreements, which are not well described in the literature, were more common than we expected with over one-third of US medical schools reporting articulation agreements with 4-year universities. Further exploration of the content of these agreements and their success in meeting intended goals is needed to fully understand their potential.

Though community college is a common route to higher education for students from rural and disadvantaged backgrounds, and data suggest that students who attended community colleges are more likely to enter family medicine $e^{60,61}$ and care for underserved populations, schools conducted less outreach to community colleges. Academic enhancement and admissions preparation with community college students were less common. Community college students may benefit most from these outreach efforts. Medical schools could seek out such agreements with community colleges as an additional strategy to recruit students likely to meet the social mission.

In the 2017 AAMC Medical School Enrollment survey, 93\% of schools reported a program targeted at students from disadvantaged backgrounds; $62 \%$ reported rural admissions programs directed toward students from rural communities; $56 \%$ from underserved communities; and $71 \%$ from local underserved communities. ${ }^{62}$ The AAMC also reported that nearly $90 \%$ have outreach programs with high schools and 4-year universities and fewer relationships with community colleges. The nature of this outreach is not reported and is an important area for further research. The AAMC did not report on admission programs directed toward the primary care workforce. Our results from 2018 show a higher number of schools reporting targeted programs and a similar number of schools reporting outreach to undergraduate institutions. This may be due to our inclusion of osteopathic schools, or higher response among schools for whom these issues are salient (though we noted few significant differences between responding and nonresponding school characteristics). Nevertheless, both our study and the AAMC survey demonstrate an awareness of unmet workforce needs for rural and urban underserved communities.

Level of research funding, student academic metrics and school reputation are common ways to evaluate medical schools. Social mission metrics have also been proposed as a way to evaluate medical schools and the return on public investment in both public and private schools. ${ }^{1}$ Others call for admissions metrics to include not only how graduates fare on specialty boards and other academic measures of success but also career outcomes like specialty choice and location of practice. ${ }^{24,30,63,64}$ If medical schools are to move toward social accountability, examining and understanding targeted admissions strategies to meet social goals is necessary.

This is the first study that characterized targeted admissions processes in US medical schools nationally-from recruitment to selection. It examined allopathic and osteopathic schools and asked a wider array of questions than previous surveys. Despite a high response rate of $71.8 \%$, we may have missed some schools with targeted admissions. Admissions deans may not be the most knowledgeable on 
targeted recruitment. Our survey questions were purposefully general and may have falsely led some schools to report targeting such applicants. However, this ensured the greatest opportunity to understand schools' strategies.

Characteristics of applicants likely to practice in these ways were previously described. However, the best ways to find and recruit these applicants; the best practices for screening, interviewing, and evaluating applicants for admission; and the efficacy of articulation agreements to produce these physicians are areas for further research. Our findings will be of interest to family medicine educators, proponents of the $25 \times 2030$ initiative, and policy makers invested in closing workforce gaps and ensuring that medical schools meet public needs. Understanding how schools target students likely to practice in rural and urban underserved locations, as well as in primary care, is the first step in identifying best practices for selective admissions focused on addressing these workforce misalignments.

FINANCIAL SUPPORT: This study was supported by the Bureau of Health Workforce (BHW), Health Resources and Services Administration (HRSA), US Department of Health and Human Services (HHS) under cooperative agreement \#UH1HP29966. The information, conclusions, and opinions expressed in this article are those of the authors and no endorsement by BHW, HRSA or HHS is intended or should be inferred.

PRESENTATIONS: Portions of the material in this study were presented in the following venues:

Northwest Rural Health Conference, SeaTac, WA, March 26, 2019.

Association of American Medical Colleges Health Workforce Research Conference, Alexandria, VA, May 2, 2019.

National Rural Health Association Annual Conference, Atlanta, GA, May 8, 2019.

RTT Collaborative Annual Meeting, Auburn, ME, May 16, 2019.

AcademyHealth Annual Research Meeting, Washington, DC, June 3, 2019.

3RNet Annual Conference, Wichita, KS, September 25, 2019.

CORRESPONDING AUTHOR: Address correspondence to Dr David V. Evans, Department of Family Medicine, University of Washington School of Medicine, $331 \mathrm{NE}$ Thornton Place, Box 358732, Seattle, WA 98125. 206-520-2410. evansd9@uw.edu.

\section{References}

1. Mullan F, Chen C, Petterson S, Kolsky G, Spagnola $\mathrm{M}$. The social mission of medical education: ranking the schools. Ann Intern Med. 2010;152(12):804-811.

2. Mian O, Hogenbirk JC, Marsh DC, Prowse O, Cain M, Warry W. Tracking Indigenous Applicants Through the Admissions Process of a Socially Accountable Medical School. Acad Med. 2019;94(8):1211-1219.

3. Petterson SM, Liaw WR, Phillips RL Jr, Rabin DL, Meyers DS, Bazemore AW. Projecting US primary care physician workforce needs: 20102025. Ann Fam Med. 2012;10(6):503-509.

4. Dall T, West T, Chakrabarti R, Iacobucci W. The Complexities of Physician Supply and Demand: Projections From 2013 to 2025. Washington, DC: Prepared for the Association of American Medical Colleges; 2015.

5. National Rural Health Association. About Rural Health Care - NRHA. https://www.ruralhealthweb.org/about-nrha/about-rural-healthcare. Accessed November 26, 2019.

6. Grumbach K, Hart LG, Mertz E, Coffman J, Palazzo L. Who is caring for the underserved? A comparison of primary care physicians and nonphysician clinicians in California and Washington. Ann Fam Med. 2003;1(2):97-104.

7. Report of the Graduate Medical Education National Advisory Committee to the Secretary, Department of Health and Human Services. Volume 1: Summary. Hyattsville, MD: Health Resources Administration (DHHS); 1980. https://files.eric.ed.gov/fulltext/ED210990.pdf. Accessed May 15, 2020.

8. Association of American Medical Colleges. AAMC Statement on the Physician Workforce. Washington, DC: AAMC; 2006.

9. Association of American Medical Colleges. Medical School Enrollment to Approach 30 Percent Increase by 2019. AAMC Newsroom. https://www.aamc.org/newsroom/newsreleases/431036/20150430.html. Published April 30, 2015. Accessed April 19, 2019.

10. Smith-Barrow D. As D.O. Medical Schools Expand, Applicants Have More Choices. US News \& World Report. https://www.usnews. com/education/best-graduate-schools/top-medical-schools/articles/2015/06/23/as-do-medicalschools-expand-applicants-have-more-choices. Published June 23, 2015. Accessed April 19, 2019.

11. Shipman SA, Wendling A, Jones KC, KovarGough I, Orlowski JM, Phillips J. The decline in rural medical students: a growing gap in geographic diversity threatens the rural physician workforce. Health Aff (Millwood). 2019;38(12):2011-2018.

12. National Resident Matching Program. Results and Data: 2019 Main Residency Match. Washington, DC: National Resident Matching Program; 2019. https://mk0nrmp3oyqui6wqfm. kinstacdn.com/wp-content/uploads/2019/04/ NRMP-Results-and-Data-2019_04112019_final.pdf. Accessed August 30, 2019.

13. American Academy of Family Physicians. 2019 Match Results for Family Medicine. https:// www.aafp.org/medical-school-residency/program-directors/nrmp.html. Accessed September 10, 2019.
14. Hughes S, Zweifler J, Schafer S, Smith MA, Athwal S, Blossom HJ. High school census tract information predicts practice in rural and minority communities. J Rural Health. 2005;21(3):228-232.

15. Wade ME, Brokaw JJ, Zollinger TW, et al. Influence of hometown on family physicians' choice to practice in rural settings. Fam Med. 2007;39(4):248-254.

16. Rabinowitz HK, Diamond JJ, Markham FW, Santana AJ. The relationship between entering medical students' backgrounds and career plans and their rural practice outcomes three decades later. Acad Med. 2012;87(4):493-497.

17. Halaas GW, Zink T, Finstad D, Bolin K, Center B. Recruitment and retention of rural physicians: outcomes from the rural physician associate program of Minnesota. J Rural Health. 2008;24(4):345-352.

18. Zink T, Center B, Finstad D, et al. Efforts to graduate more primary care physicians and physicians who will practice in rural areas: examining outcomes from the university of Minnesota-duluth and the rural physician associate program. Acad Med. 2010;85(4):599604.

19. Wendling AL, Phillips J, Short W, Fahey C, Mavis $B$. Thirty years training rural physicians: outcomes from the Michigan State University College of Human Medicine Rural Physician Program. Acad Med. 2016;91(1):113-119.

20. Xu G, Fields SK, Laine C, Veloski JJ, Barzansky B, Martini CJ. The relationship between the race/ethnicity of generalist physicians and their care for underserved populations. Am J Public Health. 1997;87(5):817-822.

21. Rabinowitz HK, Diamond JJ, Veloski JJ, Gayle JA. The impact of multiple predictors on generalist physicians' care of underserved populations. Am J Public Health. 2000;90(8):12251228.

22. Brooks RG, Mardon R, Clawson A. The rural physician workforce in Florida: a survey of US- and foreign-born primary care physicians. J Rural Health. 2003;19(4):484-491.

23. Johnson DG, Lloyd SM Jr, Miller RL. A second survey of graduates of a traditionally black college of medicine. Acad Med. 1989;64(2):87-94.

24. Rabinowitz HK, Diamond JJ, Markham FW, Santana A.J. The relationship between matriculating medical students' planned specialties and eventual rural practice outcomes. Acad Med. 2012;87(8):1086-1090.

25. Association of American Medical Colleges. Underrepresented in Medicine Definition - Initiatives. https://www.aamc.org/initiatives/urm/. Accessed April 19, 2019.

26. Walker KO, Moreno G, Grumbach K. The association among specialty, race, ethnicity, and practice location among California physicians in diverse specialties. J Natl Med Assoc. 2012;104(1-2):46-52.

27. Lupton K, Vercammen-Grandjean C, Forkin J, Wilson E, Grumbach K. Specialty choice and practice location of physician alumni of University of California premedical postbaccalaureate programs. Acad Med. 2012;87(1):115-120. 
28. Goodfellow A, Ulloa JG, Dowling PT, et al. Predictors of primary care physician practice location in underserved urban or rural areas in the United States: a systematic literature review. Acad Med. 2016;91(9):1313-1321.

29. Rabinowitz HK, Diamond JJ, Markham FW, Rabinowitz C. Long-term retention of graduates from a program to increase the supply of rural family physicians. Acad Med. 2005;80(8):728-732.

30. Greer T, Kost A, Evans DV, et al. The WWAMI Targeted Rural Underserved Track (TRUST) Program: an innovative response to rural physician workforce shortages. Acad Med. 2016;91(1):65-69.

31. Henry JA, Edwards BJ, Crotty B. Why do medical graduates choose rural careers? Rural Remote Health. 2009;9(1):1083.

32. Quinn KJ, Kane KY, Stevermer JJ, et al. Influencing residency choice and practice location through a longitudinal rural pipeline program. Acad Med. 2011;86(11):1397-1406.

33. Rabinowitz HK, Diamond JJ, Markham FW, Santana AJ. Increasing the supply of rural family physicians: recent outcomes from Jefferson Medical College's Physician Shortage Area Program (PSAP). Acad Med. 2011;86(2):264269.

34. American Association of Colleges of Osteopathic Medicine. U.S. Colleges of Osteopathic Medicine. https://www.aacom.org/become-adoctor/us-coms. Accessed April 19, 2019.

35. American Osteopathic Association. Osteopathic Medical Schools. https://osteopathic.org/about/ affiliated-organizations/osteopathic-medicalschools/. Accessed April 19, 2019.

36. Association of American Medical Colleges. Participating Medical Schools and Deadlines. https://students-residents.aamc.org/applyingmedical-school/article/participating-medicalschools-deadlines/. Accessed April 19, 2019.

37. Owen JA, Conaway MR, Bailey BA, Hayden GF. Predicting rural practice using different definitions to classify medical school applicants as having a rural upbringing. J Rural Health. 2007;23(2):133-140.

38. Orzanco MG, Lovato C, Bates J, Slade S, Grand'Maison P, Vanasse A. Nature and nurture in the family physician's choice of practice location. Rural Remote Health. 2011;11(3):1849.

39. Pepper CM, Sandefer RH, Gray MJ. Recruiting and retaining physicians in very rural areas. $J$ Rural Health. 2010;26(2):196-200.

40. Matsumoto M, Inoue K, Kajii E. Characteristics of medical students with rural origin implications for selective admission policies. Health Policy. 2008;87(2):194-202.

41. Puddey IB, Playford DE, Mercer A. Impact of medical student origins on the likelihood of ultimately practicing in areas of low vs high socio-economic status. BMC Med Educ. 2017;17(1):1.

42. Keith SN, Bell RM, Swanson AG, Williams AP. Effects of affirmative action in medical schools. A study of the class of 1975 . N Engl J Med. 1985;313(24):1519-1525.
43. Phillips RL, Dodoo MS, Petterson S, et al Specialty and Geographic Distribution of the Physician Workforce: What Influences Medical Student \& Resident Choices? Washington, DC: The Robert Graham Center; 2009:102 http://www.graham-center.org/online/etc/medialib/graham/documents/publications/mongraphs-books/2009/rgcmo-specialty-geographic. Par.0001.File.tmp/Specialty-geography-compressed.pdf. Accessed May 15, 2020.

44. Sokal-Gutierrez K, Ivey SL, Garcia RM, Azzam A. Evaluation of the Program in Medical Education for the Urban Underserved (PRIMEUS) at the UC Berkeley-UCSF Joint Medical Program (JMP): the first 4 years. Teach Learn Med. 2015;27(2):189-196.

45. Corbie-Smith G, Frank E, Nickens H. The intersection of race, gender, and primary care: results from the Women Physicians' Health Study. J Natl Med Assoc. 2000;92(10):472-480.

46. Senf JH, Campos-Outcalt D, Kutob R. Factors related to the choice of family medicine: a reassessment and literature review. J Am Board Fam Pract. 2003;16(6):502-512.

47. Newton DA, Grayson MS, Whitley TW. What predicts medical student career choice? J Gen Intern Med. 1998;13(3):200-203.

48. Schubot DB, Cayley W Jr, Eliason BC. Personal values related to primary care specialty aspirations. Fam Med. 1996;28(10):726-731.

49. Owen JA, Hayden GF, Connors AF Jr. Can medical school admission committee members predict which applicants will choose primary care careers? Acad Med. 2002;77(4):344-349.

50. Schofield JR. New and Expanded Medical Schools, Mid-Century to the 1980s: An Analysis of Changes and Recommendations for Improving the Education of Physicians. San Francisco: Jossey-Bass; 1984.

51. President's Commission of the Health Needs of the Nation. Building America's Health: Findings and Recommendations. Harry S. Truman Library Public Papers. 1952:80-319. https:// www.trumanlibrary.org/publicpapers/index. php?pid=2096. Accessed April 19, 2019.

52. American Medical Association Council on Medical Education. Critique of the Coggeshall report "planning for medical progress through education”. JAMA. 1966;197(11):909-912.

53. American Academy of Family Physicians America Needs More Family Doctors: 25x2030. https://www.aafp.org/about/initiatives/familydoctor-expansion.html. Accessed December 3, 2019.

54. American Association of Colleges of Osteopathic Medicine. AACOM 2018-2019 Academic Year Graduating Seniors Survey Summary Report. December:1-44. https:// www.aacom.org/docs/default-source/dataand-trends/aacom-2018-2019-academic-yeargraduating-seniors-survey-summary-report. pdf?sfvrsn=b5310e97_4. Accessed February 25, 2020

55. Cronenwett L, Dzau V. Who Will Provide Primary Care and How Will They Be Trained? In: Culliton B, Russel S, eds. Proceedings of a Conference Sponsored by the Josiah Macy, Jr. Foundation. Durham, NC: Josiah Macy, Jr. Foundation; 2010:260.
56. Association of American Medical Colleges AAMC Medical School Graduation Questionnaire: 2019 All Schools Summary Report. Washington, DC: AAMC; 2019.

57. Phillips JP, Wendling A, Bentley A, Marsee R, Morley CP. Trends in US Medical School Contributions to the Family Physician Workforce: 2018 Update From the American Academy of Family Physicians. Fam Med. 2019;51(3):241250.

58. Davis D, Dorsey JK, Franks RD, Sackett PR, Searcy CA, Zhao X. Do racial and ethnic group differences in performance on the MCAT exam reflect test bias? Acad Med. 2013;88(5):593-602.

59. Longo DR, Gorman RJ, Ge B. Rural medical school applicants: do their academic credentials and admission decisions differ from those of nonrural applicants? J Rural Health. 2005;21(4):346-350.

60. Talamantes E, Mangione CM, Gonzalez K, Jimenez A, Gonzalez F, Moreno G. Community college pathways: improving the U.S. physician workforce pipeline. Acad Med. 2014;89(12):1649-1656.

61. Talamantes E, Jerant A, Henderson MC, et al. Community College Pathways to Medical School and Family Medicine Residency Training. Ann Fam Med. 2018;16(4):302-307.

62. Results of the 2017 Medical School Enrollment Survey. Washington, DC: Association of American Medical Colleges; 2018. https://store. aamc.org/results-of-the-2017-medical-schoolenrollment-survey.html. Accessed September 11, 2019.

63. Young ME, Thomas A, Varpio L, et al. Facilitating admissions of diverse students: A six-point, evidence-informed framework for pipeline and program development. Perspect Med Educ. 2017;6(2):82-90

64. Morley CP, Mader EM, Smilnak T, et al. The social mission in medical school mission statements: associations with graduate outcomes. Fam Med. 2015;47(6):427-434.

65. Nicholson GC, Kondalsamy-Chennakesavan S. Determinants of rural practice: positive interaction between rural background and rural undergraduate training. Med J Aust. 2015;202(9):477-479.

66. Hancock C, Steinbach A, Nesbitt TS, Adler SR, Auerswald CL. Why doctors choose small towns: a developmental model of rural physician recruitment and retention. Soc Sci Med. 2009;69(9):1368-1376.

67. Kawamoto R, Uemoto A, Ninomiya D, et al. Characteristics of Japanese medical students associated with their intention for rural practice. Rural Remote Health. 2015;15(2):3112.

68. Manusov EG, Livingston H, Stine C, Van Durme D. Toward a common framework for rural background. Fam Med. 2010;42(10):732735 .

69. Senf JH, Campos-Outcalt D, Kutob R. Family medicine specialty choice and interest in research. Fam Med. 2005;37(4):265-270.

70. Scott I, Wright B, Brenneis F, Brett-Maclean P, McCaffrey L. Why would I choose a career in family medicine?: reflections of medical students at 3 universities. Can Fam Physician. 2007;53(11):1956-1957. 